Tohoku J. exp. Med., 1984, 142, 227-228

Short Report

\title{
Serological Survey of Hepatitis B Virus (HBV) Markers in Out- and In-patients in a University Hospital
}

\author{
Osamu Nakagomi, Tsuneko Suzuki, Hajime Oyamada, \\ Eiko Kaneda, Yumiko Saruta and Shiro Uesugi \\ Department of Laboratory Medicine, Akita University \\ Hospital, Akita 010
}

\begin{abstract}
Nakagomi, O., Suzuki, T., Oyamada, H., Kaneda, E., Saruta, Y. and Uesugi, S. Serological Survey of Hepatitis B Virus (HBV) Markers in Out-and In-Patients in a University Hospital. Tohoku J. exp. Med., 1984, 142(2), 227-228 — Of a total of 13,596 patients and 1,876 blood donors in a university hospital examined, $550(4.1 \%)$ patients and $31(1.7 \%)$ donors possessed hepatitis B surface antigen ( $\mathrm{HBsAg}$ ) in their blood. The higher incidence of HBsAg in the patient population than in the blood donors verified the view that medical personnel and hospitalized patients are at increased risk of acquiring HBV infection. To assess the actual hazard of the HBsAg-positive patients, we examined hepatitis Be antigen ( $\mathrm{HBeAg}$ ) and its antibody (anti-HBe) status of $228 \mathrm{HBsAg}$-positive patients and found that $39(18 \%)$ were positive for $\mathrm{HBeAg}$ and $168(74.5 \%)$ were positive for anti-HBe. This indicated that only one fifth of the HBsAg-positive patients should be drawn attention in terms of HBV transmission within a hospital. — $\mathrm{HBsAg}$; $\mathrm{HBeAg}$; anti-HBe ; seroepidemiology
\end{abstract}

Hepatitis B virus (HBV) infection within hospitals has been recognized as an occupational hazard in the health care profession (Maynard 1978). The prevalence of hepatitis B surface antigen ( $\mathrm{HBsAg}$ ) and its antibody was investigated well in medical and dental personnel, while not many works were done to clarify the prevalence of HBV markers among the patient population (Maynard 1978). The present study was undertaken to reveal the incidence of $\mathrm{HBsAg}$ among out- and in-patients in a university hospital and to characterize the HBsAg-positive patients in terms of hepatitis B e antigen ( $\mathrm{HBeAg}$ ) and its antibody (anti-HBe) status in order to clarify their actual infectivity.

Sera of 13,596 patients and 1,876 blood donors collected from March 1980 to October 1982 were tested for HBsAg by enzyme immunoassay (Auszyme II, Abbott Laboratories, North Chicago, IL.). HBeAg and anti-HBe were also determined by enzyme immunoassay (HBe EIA, Abbott Laboratories) on $228 \mathrm{HBsAg}$-positive sera with sufficient volume.

Table 1 shows the frequency of HBsAg detected among the patients and blood donors. The prevalence of HBsAg in the patients population $(4.1 \%$ ) was more than twice that of the blood donors which was similar to the prevalence of the HBV carriers in Japan. Our result supported the previous work (Maynard 1978) that the frequency of HBsAg in the hospital admissions was approximately twice that in the general population and verified the view that medical personnel and hospitalized patients are at increased risk of incurring HBV infection.

When we consider the control and prevention of HBV transmission within a hospital,

Received for publication, May 16, 1983. 
TABle 1. Prevalence of HBsAg detected by enzyme immunoassay in the out-, in-patients and blood donors

\begin{tabular}{lccc}
\hline & $\begin{array}{c}\text { Number of } \\
\text { cases tested }\end{array}$ & $\begin{array}{c}\text { Number of } \\
\text { positive cases }\end{array}$ & $\%$ \\
\hline Patients & 13,596 & 550 & $4.1^{*}$ \\
Out-patients & 7,671 & 258 & 3.4 \\
In-patients & 5,925 & 292 & 4.9 \\
Blood donors & 1,876 & 31 & $1.7^{*}$ \\
\hline
\end{tabular}

* The difference is statistically significant $(p=0.001)$

TABLE 2. $\mathrm{HBe} /$ anti-HBe status of $228 \mathrm{HBs} \mathrm{Ag}$-positive patients

\begin{tabular}{ccccc}
\hline & $\begin{array}{l}\mathrm{HBeAg}(+) \\
\text { anti-HBe (-) }\end{array}$ & $\begin{array}{l}\mathrm{HBeAg}(+) \\
\text { anti-HBe }(+)\end{array}$ & $\begin{array}{l}\mathrm{HBeAg}(-) \\
\text { anti-HBe (-) }\end{array}$ & $\begin{array}{l}\text { HBeAg (-) } \\
\text { anti-HBe (+) }\end{array}$ \\
\hline $\begin{array}{c}\text { Number of } \\
\text { patients }(\%)\end{array}$ & $39(18.0)$ & $3(1.5)$ & $18(6.0)$ & $168(74.5)$ \\
\hline
\end{tabular}

further characterization of $\mathrm{HBsAg}$-positive patients in regard to $\mathrm{HBe}$ /anti-HBe status is of practical importance. When we examined the $\mathrm{HBe} /$ anti-HBe status of $228 \mathrm{HBsAg}$-positive patients, only $18 \%$ was revealed to have $\mathrm{HBeAg}$ while $74.5 \%$ possessed anti-HBe (Table 2). These figures resembled the prevalence of $\mathrm{HBeAg}(19 \%)$ and anti-HBe $(81 \%)$ in the asymptomatic carriers of $\mathrm{HBV}$ rather than that in patients with chronic liver diseases in which the ratio of $\mathrm{HBeAg}$ and anti-HBe was approximately 1:1 (Fukuda et al. 1981). Three patients $(1.5 \%)$ were shown to have both $\mathrm{HBeAg}$ and anti-HBe in their blood. This coexistence of $\mathrm{HBeAg}$ and anti-HBe was reported in patients who were in the way of the seroconversion from $\mathrm{HBeAg}$ to anti-HBe (Suzuki et al. 1981). It has been established that $\mathrm{HBeAg}$ is a reliable marker of high infectivity and that anti-HBe, on the contrary, suggestive of very low infectivity, if not at all (Miyakawa and Mayumi 1982). In conclusion, it is true that medical personnel is at risk of incurring $\mathrm{HBV}$ infection but only the minority (one fifth in our study) of $\mathrm{HBsAg}$-positive patients incur a risk of $\mathrm{HBV}$ infection within a hospital and the interruption of $\mathrm{HBV}$ transmission should be accomplished by careful precautions when dealing with the infectious patients, their blood and their excretions.

\section{References}

1) Fukuda, Y., Kawasaki, T., Miyamura, M., Sugiyama, T., Sano, M., Nakano, H., Imura, H., Shimizu, T. \& Ito, K. (1981) Prevalence of HBeAg and HBeAg in the patients with primary hepatocellular carcinoma. Acta hepatol. jap., 22, 859-865. (Japanese)

2) Maynard, J.E. (1978) Viral hepatitis as an occupational hazard in health care profession. In: Viral Hepatitis, edited by G.N. Vyas, S.N. Cohen \& R. Schmid, The Franklin Institute Press, Philadelphia, pp. 321-331.

3) Miyakawa, Y. \& Mayumi, M. (1982) HBeAg-anti HBe system in hepatitis B virus infection. In: Viral Hepatitis, edited by W. Szmuness, H.J. Alter \& J.E. Maynard, The Franklin Institute Press, Philadelphia, pp. 183-194.

4) Suzuki, H., Matsushima, T., Miyazaki, T., Toyoda, J., Okuuchi, Y. \& Ito, H. (1981) Determination of $\mathrm{HBe}$ antigen and its antibody by means of radioimmunoassay. Acta hepatol. jap., 22, 1518-1524. (Japanese) 